\title{
An Experimental Study of Possible Post-War Ferronickel Slag Waste Disposal in Szklary (Lower Silesian, Poland) as Partial Aggregate Substitute in Concrete: Characterization of Physical, Mechanical, and Thermal Properties
}

\author{
Marcin Małek $^{1}$ (D), Mateusz Jackowski ${ }^{1, *(D)}$, Waldemar Lasica ${ }^{1}$ (D) Kamil Dydek ${ }^{2}$ and Anna Boczkowska $^{2}(\mathbb{D}$ \\ 1 Faculty of Civil Engineering and Geodesy, Military University of Technology, ul. Gen. Sylwestra Kaliskiego 2, \\ 00-908 Warsaw, Poland; marcin.malek@wat.edu.pl (M.M.); waldemar.lasica@wat.edu.pl (W.Ł.) \\ 2 Faculty of Materials Science and Engineering, Warsaw University of Technology, ul. Wołoska 141, \\ 02-507 Warsaw, Poland; kamil.dydek@pw.edu.pl (K.D.); anna.boczkowska@pw.edu.pl (A.B.) \\ * Correspondence: mateusz.jackowski@wat.edu.pl; Tel.: +48-511-06-05-77
}

check for updates

Citation: Małek, M.; Jackowski, M.; Łasica, W.; Dydek, K.; Boczkowska, A An Experimental Study of Possible Post-War Ferronickel Slag Waste Disposal in Szklary (Lower Silesian, Poland) as Partial Aggregate Substitute in Concrete:

Characterization of Physical, Mechanical, and Thermal Properties. Materials 2021, 14, 2552. https:// doi.org/10.3390/ma14102552

Academic Editors: Miguel Bravo, Rui Vasco Silva and António P.C. Duarte

Received: 5 April 2021

Accepted: 11 May 2021

Published: 14 May 2021

Publisher's Note: MDPI stays neutral with regard to jurisdictional claims in published maps and institutional affiliations.

Copyright: (c) 2021 by the authors. Licensee MDPI, Basel, Switzerland. This article is an open access article distributed under the terms and conditions of the Creative Commons Attribution (CC BY) license (https:// creativecommons.org/licenses/by/ $4.0 /)$.

\begin{abstract}
Aggregates derived from waste, due to the growing awareness of global warming, are more and more often used in the concrete production process. This way, their disposal not only reduces the pollution of the Earth but also lowers the consumption of natural aggregates, which are limited. One of the new "eco" aggregates may be a ferronickel slag waste (FNSW), which was generated in postwar metallurgical processes and stored in Szklary (Lower Silesian, Poland). In order to determine the possibility of using ferronickel slag waste aggregate (FNSWA) in the concrete production process, new concrete mixtures were designed and tested. Physical properties (cone slump, air content, $\mathrm{pH}$, and density), mechanical properties (compressive strength, flexural strength, and tensile strength), and thermal properties (thermal conductivity) were assessed for all new laboratory recipes. Moreover, the modulus of elasticity and Poisson's ratio were determined. This study includes five different contents of FNSWA in the amount of $5 \%, 10 \%, 15 \%, 20 \%$, and $25 \%$ of the mass of natural aggregate as its partial substitute. The final results were compared to the base sample (BS) containing 100\% natural aggregate, which was granite.
\end{abstract}

Keywords: ferronickel slag waste; by-products; waste disposal; recycling; eco-efficient concrete mixture; concrete modifications

\section{Introduction}

The war period was particularly severe for Poland. A significant number of the country's population died, defending their homeland, some lands were taken away, and the losses in the infrastructure were difficult to accurately quantify. It is estimated that the war cost that one resident had to pay was around USD 626 [1]. Despite the initial difficulties however, the reconstruction of the country has begun, thus implementing recovery plans. One of them, the Six-Year Plan, assumed the development of the metallurgical industry due to the large amount of natural resources and minerals present in Poland. The priority of the plan was to increase investment and the policy of intensive induction of the country on the soviet model. According to the Six-Year Plan, the industrial production alone was to increase by $85-95 \%$ [2-4], which could not have had a good environmental impact.

The post-war development of the polish industry has left its mark on the environment by leaving soil and groundwater contamination, and a large amount of waste that remains to this day $[5,6]$. This phenomena is especially visible in Silesian Districts of Southern and South-Western Poland where coal-waste dumps are stored. The enormous amounts of material from coal mining and coal production, due to the intense coal exploitation that has begun in the 19th century, is accumulated on dumps [7]. These materials are exposed to processes of self-heating, water-washing, and biodegradation, which can lead to significant 
environmental problems around coal-waste dumps, such as high concentrations of toxic compounds in soil or acidic gases and chemicals in the air [8]. Therefore, not only the environment but also human and animal life may be in danger. However, coal-waste is not the only type of waste left after the post-war development of the polish industry. Another big problem lies in South-Western Poland in Lower Silesian voivodeship. A small village, Szklary, within Zabkowice Ślaskie County, is a place where up until 1982 the only nickel ore mine in Poland was located. It has been officially closed due to the unprofitability of further exploitation but huge amounts of ferronickel slag waste are accumulated there to this day [9-11]. As it is stored in dumps, similar processes to coal-waste dumps occur. This work is a proposal of ferronickel slag waste utilization in concrete mixtures to prevent further contamination of groundwater, soil, and air spreading across Ząbkowice Śląskie County, especially Szklary.

Waste and by-products from other industry branches can be re-used by the construction industry as a component of concrete and mortar [12-15]. According to current studies, they can be used as a replacement of natural aggregate [16] and cement [17], as dispersed reinforcement [18-21] to lower surface stress and prevent microcracks or as a filler to increase thermal properties of final composite [22]. Ferronickel slag waste has a potential to substitute natural aggregate as it is a solid discharged from the smelting process of metal nickel or nickel-iron alloy. What is worth mentioning is that it has a high density and durability. Such properties are obtained in the heating and calcining process of nickel, where it is bonded with iron oxide. Moreover, this fusion allows high resistance to corrosion, heat shock, and fatigue, as well as the ferromagnetic effect of the final material [23].

The possibility of ferronickel slag waste utilization in concrete has been studied during recent years by Saha et al. [24-27]. As they reported, a 50\% replacement of natural sand with FNSWA increases compressive strength from 38 to $57 \mathrm{MPa}$ in concrete [26]. What was unexpected, other mechanical properties also showed higher values compared to plain concrete. Saha et al. noted about $7 \%$ and $13 \%$ increase in split tensile strength and flexural strength, respectively. Similar trends were observed by Nguyen et al. [28] as they reported an increase in concrete performance containing ferronickel sand as a fine aggregate. They pointed out, that both, mechanical and durability properties increased, due to the better interfacial transition zone between ferronickel aggregate and cement paste. Nuruzzaman et al. [29] also tested ferronickel slag waste as an aggregate replacement. With the density of $2920 \mathrm{~kg} / \mathrm{m}^{3}$ and substitution in range from $20 \%$ to $60 \%$ they achieved an increase in concrete mixture workability and a decrease in water absorption of hardened samples. Furthermore, concretes containing $20 \%, 40 \%$, and $60 \%$ showed an increase by $1 \%, 34 \%$, and $31 \%$ compressive strength compared to the base mix (37 MPa), and an increase by about $2 \%, 15 \%$, and $8 \%$ split tensile strength compared to the base mix (4.3 $\mathrm{MPa})$, respectively. The same trend after replacing coarse aggregate with ferronickel was reported by Sun et al. [30] and Qi et al. [31]. However, not only mechanical and psychical properties changes have been reported after FNSWA incorporation in concrete mixture. As presented by Saha [32], ferronickel slag can lower the thermal conductivity, as well. A concrete designed by them, with $100 \%$ FNSWA, showed $1.16 \mathrm{~W} / \mathrm{mK}$ thermal conductivity, which was about two times lower compared to the base mix with only natural aggregate $(2.34 \mathrm{~W} / \mathrm{mK})$.

This study aims to contribute to this growing area of research by exploring the potential usage of FNSWA mined in Szklary (Lower Silesia, Poland) as a replacement of natural aggregate in concrete. The problem of FNSW in Lower Silesia in Poland is very serious, so far, however, no possible method of utilization of this waste has been efficiently introduced to the Polish industry. To do so, psychical, mechanical, and thermal properties on new concretes were tested. Findings presented in this study make an important contribution to the effective utilization of ferronickel slag waste accumulated in Szklary (Lower Silesia, Poland) and contribute to the environment harmed by ferronickel slag waste stored there. As it has a different mineral composition proportion compared to the ones presented in current studies it may also show different results of concrete properties, especially its 
mechanical strength. Moreover, such a replacement is consistent with the principle of sustainable development and the circular economy.

\section{Materials}

\subsection{Specimen Preparation}

Table 1 shows chemical composition and strength parameters of the Portland cement (CEM I $42.5 \mathrm{R}$ [33]) used for each concrete mixture, which were determined according to EN 196-6:2019-01 [34] and PN EN 196-1:2016-07 [35]. Moreover, all of the recipes were based on tap water (chloride content $28 \mathrm{mg} / \mathrm{l}$ ) and natural granite aggregate, used as a filler, with a fraction up to $8.0 \mathrm{~mm}$. Its grain size index $\left(C_{U}=7.2\right.$ and $\left.C_{C}=1.1\right)$ suggests that aggregate is well compacted [36] and, as presented in Figure 1, fits between upper and lower curves determined in accordance with the EN 12620+A1:2010 [37] standard.

Table 1. Chemical composition and strength parameters of the cement [38].

\begin{tabular}{|c|c|c|c|c|c|c|c|c|c|}
\hline Compositions & $\mathrm{SiO}_{2}$ & $\mathrm{Al}_{2} \mathrm{O}_{3}$ & $\mathrm{Fe}_{2} \mathrm{O}_{3}$ & $\mathrm{CaO}$ & $\mathrm{MgO}$ & $\mathrm{SO}_{3}$ & $\mathrm{Na}_{2} \mathrm{O}$ & $\mathrm{K}_{2} \mathrm{O}$ & $\mathrm{Cl}$ \\
\hline Unit (vol\%) & 19.5 & 4.9 & 2.9 & 63.3 & 1.3 & 2.8 & 0.1 & 0.9 & 0.05 \\
\hline $\begin{array}{l}\text { Specific surface area } \\
\qquad\left(\mathrm{m}^{2} / \mathrm{kg}\right)\end{array}$ & & & & & 376.3 & & & & \\
\hline Initial setting time (min) & & & & & 227 & & & & \\
\hline $\begin{array}{l}\text { Compressive strength } \\
\text { after } 2 \text { days }(\mathrm{MPa})\end{array}$ & & & & & 28.4 & & & & \\
\hline $\begin{array}{l}\text { Compressive strength } \\
\text { after } 28 \text { days (MPa) }\end{array}$ & & & & & 60.8 & & & & \\
\hline
\end{tabular}

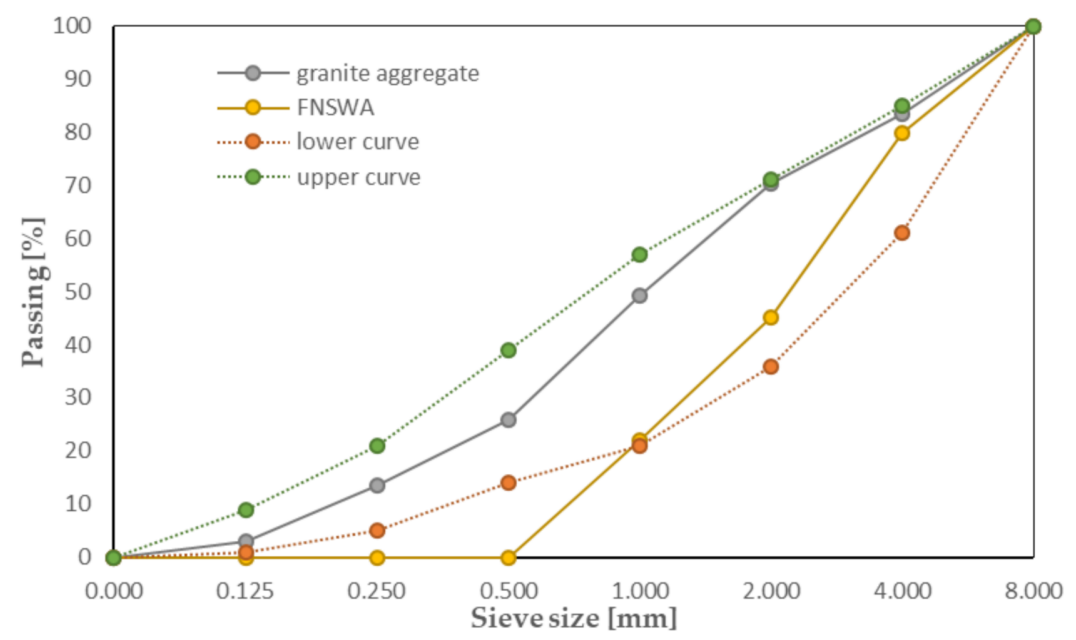

Figure 1. Gradation of crushed granite aggregate and FNSWA.

In order to increase the workability of all mixtures, but at the same time maintain the water-cement ratio $w / c$ at 0.44 , the chemical admixture was used. It was a low-alkaline liquid, free of chlorine, and based on an aqueous solution of modified polycarboxylic ethers (melamine and silanes/siloxanes), which helped reduce the accumulated water on the surface of concrete after compaction, as well [39]. The chemical composition of the chemical admixture is given in Table 2.

Table 2. Chemical composition of the admixture.

\begin{tabular}{ccccc}
\hline Compositions & $\mathbf{O}$ & $\mathbf{N a}$ & $\mathbf{S i}$ & $\mathbf{K}$ \\
\hline Unit $(\mathrm{vol} \%)$ & 77.7 & 14.9 & 4.8 & 2.6 \\
\hline
\end{tabular}




\subsection{Ferronickel Slag Waste}

As a partial substitute to natural granite aggregate, ferronickel slag waste was used (Figure 2). FNSW was mined from the ferronickel waste dump stored in Szklary, within Zabkowice Ślaskie County (Lower Silesia, Poland) and transported to the laboratory.

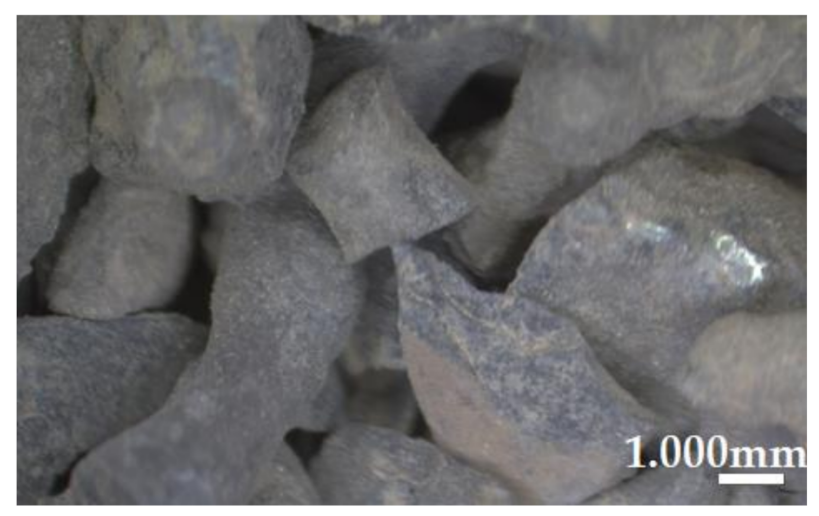

Figure 2. Ferronickel slag waste aggregate.

Table 3 presents the chemical composition of FNSW used as an aggregate substitute, the density of which is about $2750 \mathrm{~kg} / \mathrm{m}^{3}$. Compared to cement, its chemical composition is similar due to the fact that it contains a significant part of the compounds present in the binder. The FNSWA sieve curve is given in Figure 1.

Table 3. Chemical composition of FNSW.

\begin{tabular}{cccccc}
\hline Compositions & $\mathrm{SiO}_{2}$ & $\mathrm{Fe}_{2} \mathrm{O}_{3}$ & $\mathrm{Al}_{2} \mathrm{O}_{3}$ & $\mathrm{CaO}$ & $\mathrm{MgO}$ \\
\hline Unit (vol\%) & 49.8 & 24.4 & 11.9 & 9.6 & 4.3 \\
\hline
\end{tabular}

\subsection{Mix Composition}

Six different types of mortar mixtures were produced, see Table 4. The FNSWA content, which was added rather than the same amount of natural aggregate, was $5 \%, 10 \%$, $15 \%, 20 \%$, and $25 \%$ of granite mass for samples marked in the article as 5FNSW, 10FNSW, 15FNSW, 20FNSW, and 25FNSW, respectively. The sample with $100 \%$ of natural granite aggregate was marked as BM and used to compare test results.

Table 4. Mix proportions $\left(1 \mathrm{~m}^{3}\right)$.

\begin{tabular}{|c|c|c|c|c|c|}
\hline Mix Symbol & $\begin{array}{c}\text { Cement } \\
{[\mathrm{kg}]}\end{array}$ & $\begin{array}{l}\text { Water } \\
{[\mathrm{kg}]}\end{array}$ & $\begin{array}{c}\text { Chemical } \\
\text { Admixture [kg] }\end{array}$ & $\begin{array}{c}\text { Granite Aggregate } \\
{[\mathrm{kg}]}\end{array}$ & $\begin{array}{c}\text { FNSWA } \\
{[\mathrm{kg}]}\end{array}$ \\
\hline $\mathrm{BM}$ & \multirow{6}{*}{468} & \multirow{6}{*}{207} & \multirow{6}{*}{4.7} & 1600 & 0 \\
\hline 5FNSW & & & & 1520 & 80 \\
\hline 10FNSW & & & & 1440 & 160 \\
\hline 15FNSW & & & & 1360 & 240 \\
\hline 20FNSW & & & & 1280 & 320 \\
\hline $25 \mathrm{FNSW}$ & & & & 1200 & 400 \\
\hline
\end{tabular}

\subsection{Mix Production}

After mixing dry components for $1 \mathrm{~min}$, the liquid components were added to the concrete mixture, and blended together for $4 \mathrm{~min}$. Next, fresh concrete was poured into molds and compacted on a vibrating table. All of the samples were manufactured in $21^{\circ} \mathrm{C}$ temperature and $50 \%$ humidity inside a laboratory and stored in water according to EN 12390-2:2019-07 [40]. After 28 days, the samples were tested for each property. 
From each mix, the following samples were produced: Ten cubes with dimensions of $150 \times 150 \times 150 \mathrm{~mm}$, five cuboids with dimensions of $40 \times 40 \times 160 \mathrm{~mm}$, five rollers with a base diameter of $150 \mathrm{~mm}$ and a height of $300 \mathrm{~mm}$, and one tile with dimensions of $30 \times 30 \times 6 \mathrm{~mm}$. In total, 60 cubic samples, 30 cuboid samples, 30 cylinders, and six tiles were made to conduct this study.

\section{Methodology}

\subsection{Fresh Concrete Tests}

The slump cone test was carried out according to EN 12350-2:2019-07 [41], when the air content and $\mathrm{pH}$ value of the mix were determined according to EN 12350-7:2019-08 [42] and PN-B-01810:1986 [43], respectively. Five samples for each mixture were investigated. These tests were performed in a listed order and right after the mixing process was done. The presented values for the conducted tests are the average values of five samples made in pursuance of each concrete recipe.

\subsection{Hardened Concrete Tests}

The density of concrete samples, was determined according to EN 12390-7:2019-08 [44] on $150 \times 150 \times 150$ cubes. Furthermore, mechanical properties were assessed, such as compressive strength, flexural strength, and tensile strength. To do so, a Zwick machine (Zwick, Ulm, Germany) with a force range of $0-5000 \mathrm{kN}$ and maximum stress increase of $0.5 \mathrm{MPa} / \mathrm{s}$ was used. The compressive strength was measured according to EN 123903:2019-07 [45] on $150 \times 150 \times 150 \mathrm{~mm}$ samples, which were placed in the Zwick machine. Next, the compressive strength of each test was determined by dividing the maximum sample load value by the sample cross-sectional area. For the flexural strength test, in a three-point bending set-up, $40 \times 40 \times 160 \mathrm{~mm}$ concrete beams were prepared according to EN 12390-5:2019-08 [46]. The Zwick machine used for the test enabled loading with a static force and keeping it in a vertical configuration at a constant assumed level thanks to the supports that allowed only the horizontal movement (the distance between supports was $100 \mathrm{~mm}$ ). The last mechanical property, the split tensile strength, was tested on cylinders of $150 \mathrm{~mm}$ diameter and $300 \mathrm{~mm}$ height according to EN 12390-6:2011 [47]. In order to perform the test, the sample was placed in the Zwick machine on sliding supports, immobilized in the guides of the testing machine. The distance between the supports was greater than 10 diameters of the sample and the pressure head and supports were radially rounded at the point of contact with the sample. The cylinders of $150 \mathrm{~mm}$ diameter and $300 \mathrm{~mm}$ were also used to define the Modulus of elasticity and Poisson's ratio according to the EN 1239013:2014-02 [48] standard. Every sample was loaded and the load was removed in the lower and upper stress range to determine these material properties of each hardened concrete mixture. The modulus of elasticity and Poisson's ratio were determined thanks to linear displacements and measuring base lengths noted with Epsilon extensometers (Epsilon, Jackson, WY, USA). The scope of the research also included thermal conductivity. The temperature responses to the material heat flow pulses were the basis for all measurements done with the ISOMET2114 analyzer (Applied Precision Ltd., Bratislava, Slovakia). The analyzer probe, containing the resistor heater through which the heat flow was induced, had a direct contact with the tested sample. A probe with a diameter of $60 \mathrm{~mm}$ and the tested material in the form of cubes $(150 \times 150 \times 150 \mathrm{~mm})$ from each concrete mix were used.

All of the specified above tests were carried out after 28 days of the curing process. Each of them was performed on five samples of every mix and the values presented are the average values (Figure 3). 


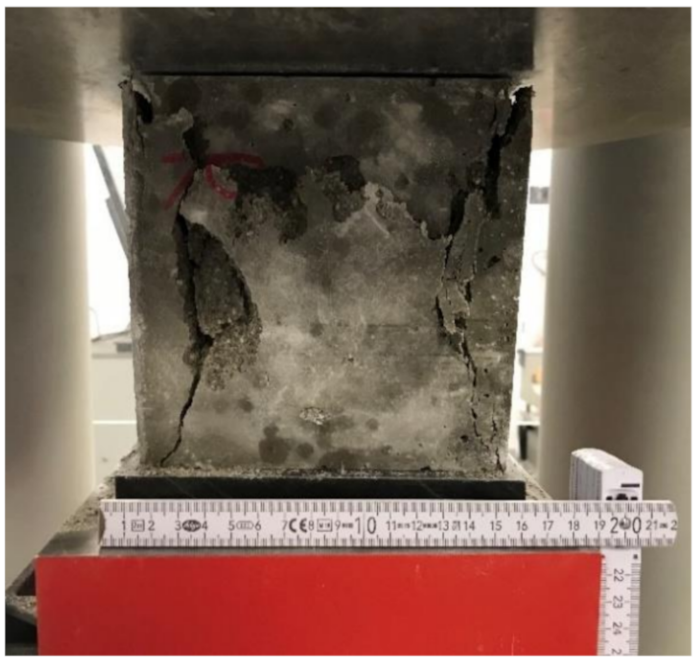

(a)

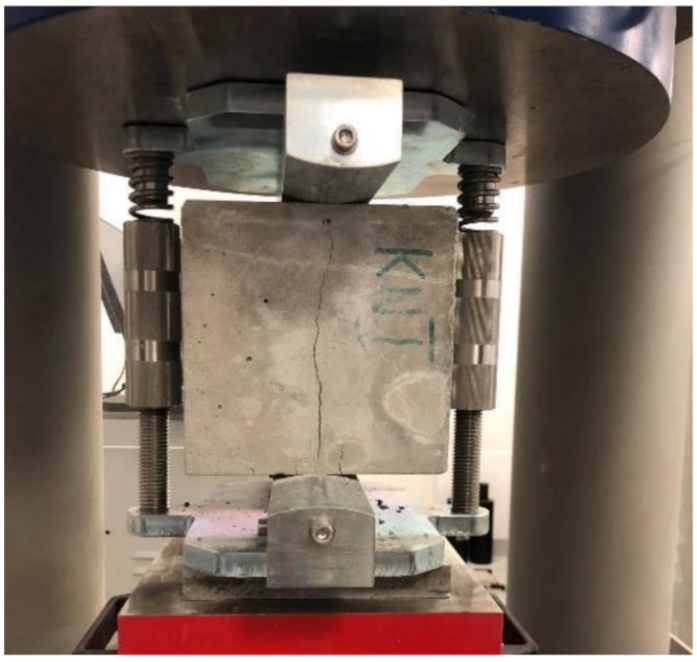

(c)

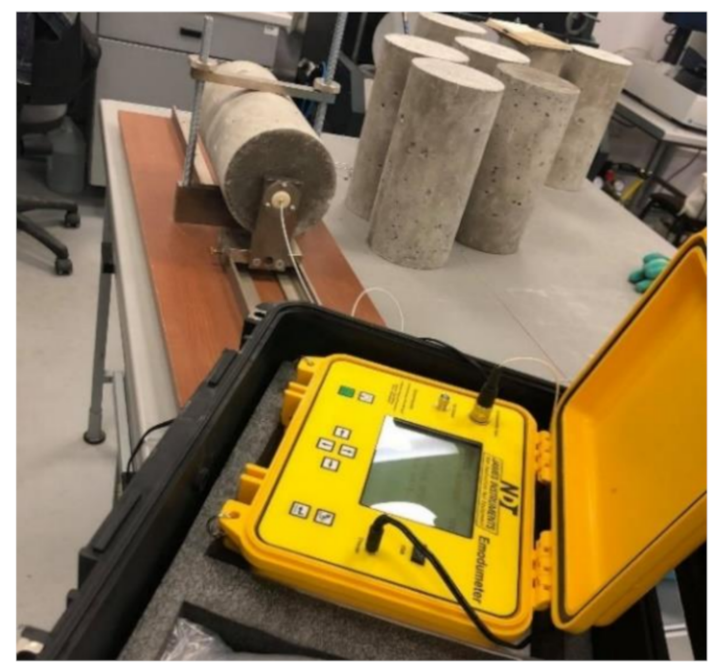

(e)

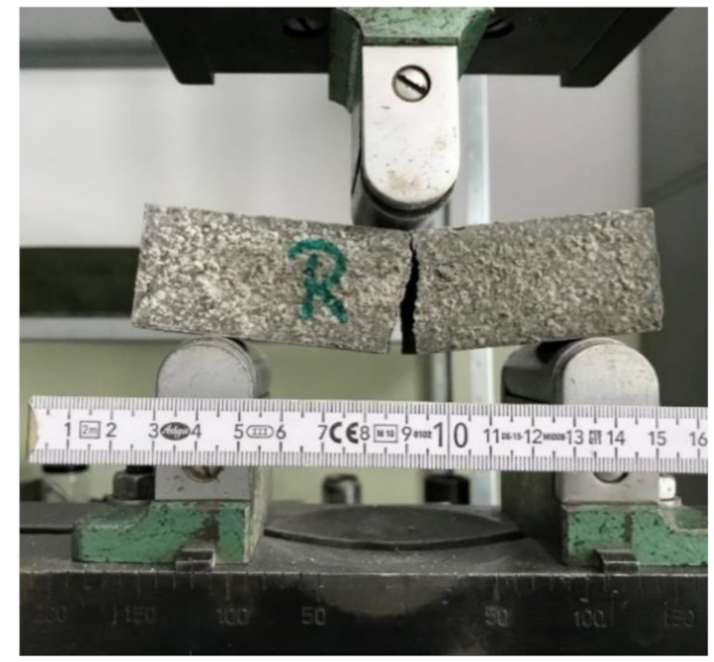

(b)

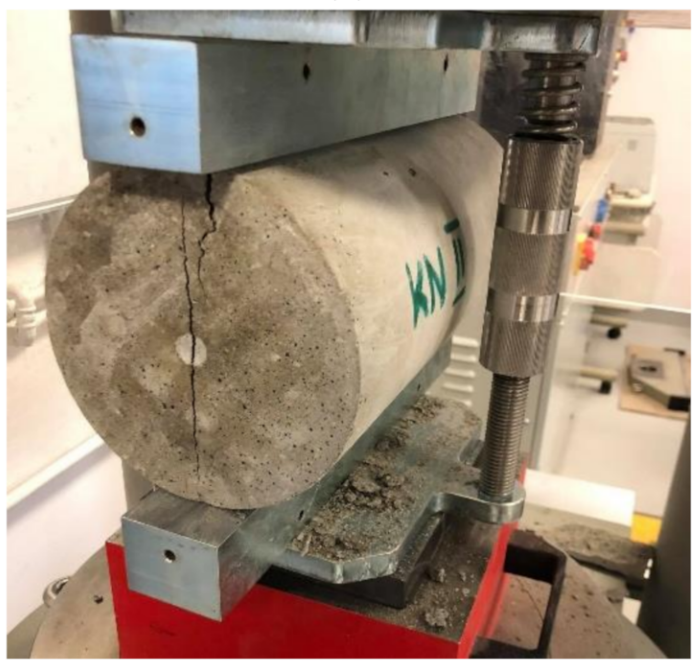

(d)

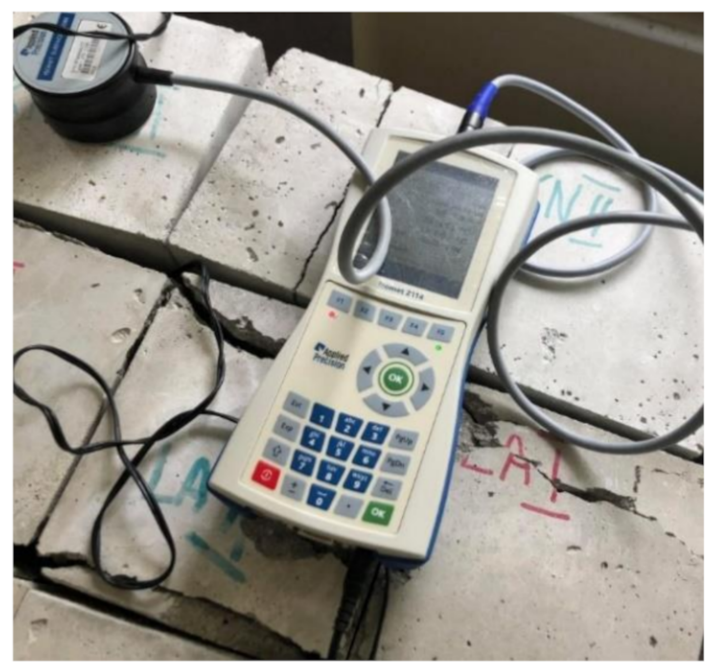

(f)

Figure 3. Photographic documentation of tests carried out: (a) Compressive strength test, (b) flexural strength test, (c) split tensile strength test—cubes, (d) split tensile strength test—cylinder, (e) elastic modulus test, (f) thermal conductivity test. 


\section{Results and Discussion}

\subsection{The Slump Cone Test}

Table 5 shows the slump cone test results of all concrete recipes. According to EN 12350-2:2019-07 [41], they could be classified as a S1 class. Analyzing the obtained results, it can be seen that the modification with ferronickel slag did not affect the cone slag at any percentage share of the natural aggregate substitute, and thus the fresh concrete consistency. All of the presented values of the slump cone fall test are in the error range. The slump cone test was also conducted by Saha et al. in their studies [24,26]. They reported however a much higher fall as the values fluctuated in the range of 200 to $230 \mathrm{~mm}$ and in the range of 120 to $150 \mathrm{~mm}$ for mortars and concretes with ferronickel slag addition, respectively. This difference in the results may be due to the higher water/cement ratio used by Saha and the smaller size of ferronickel slag waste compared to our study.

Table 5. Fresh concrete test results.

\begin{tabular}{ccccc}
\hline Mix Symbol & Slump Cone [mm] & Consistency Class [41] & Air Content [\%] & pH [-] \\
\hline BM & $2 \pm 1$ & S1 & $2.1 \pm 0.1$ & $12.61 \pm 0.03$ \\
\hline 5FNSW & $2 \pm 1$ & S1 & $2.2 \pm 0.1$ & $12.65 \pm 0.03$ \\
\hline 10FNSW & $2 \pm 1$ & S1 & $2.4 \pm 0.1$ & $12.68 \pm 0.04$ \\
\hline 15FNSW & $2 \pm 1$ & S1 & $2.7 \pm 0.1$ & $12.69 \pm 0.03$ \\
\hline 20FNSW & $2 \pm 1$ & S1 & $3.2 \pm 0.1$ & $12.71 \pm 0.03$ \\
\hline 25FNSW & $1 \pm 1$ & S1 & $3.6 \pm 0.1$ & $12.72 \pm 0.04$ \\
\hline
\end{tabular}

\subsection{Air Content}

The air content presented in Table 5 shows that the peak value of this property was reported for the $25 \mathrm{FNSW}$ sample (modified with $25 \%$ of ferronickel slag waste). It showed an increment of $1.5 \%$ compared to BM. Previous substitutions of granite aggregate also indicated a higher air content in concrete mixtures compared to BM. This phenomena may be a result of the higher grain size of FNSWA compared to the granite aggregate used in the concrete manufacturing process. It can also indicate more air voids both in fresh and hardened concrete.

\subsection{The $p H$ Test}

As presented in Table 5, the $\mathrm{pH}$ of all concrete mixtures exhibits the alkaline reaction. The highest value of $\mathrm{pH}$ was reported for samples with $25 \%$ ferronickel slag waste aggregate (12.72). Compared to the base mix values (12.61) an increase of about $1 \%$ can be noted. Such a small change may indicate that FNSWA did not affect the $\mathrm{pH}$ of the concrete mixture significantly.

\subsection{Density}

The density of concrete samples is presented in Table 6 . The substitution equal to $5 \%$, $10 \%, 15 \%, 20 \%$, and $25 \%$ of natural aggregate done with FNSWA, resulted in a density increase by $1.6 \%, 2.6 \%, 3.2 \%, 6.6 \%$, and $8.7 \%$ compared to the $\mathrm{BM}$, respectively. All of the obtained values were in the range between $2187 \pm 2 \mathrm{~kg} / \mathrm{m}^{3}(\mathrm{BM})$ and $2378 \pm 3 \mathrm{~kg} / \mathrm{m}^{3}$ (25FNSW), and, after analyzing them, an overall trend can be noted as: The higher the FNSWA amount, the higher the density of concrete, see Figure 4 . This may be a result of the higher density of FNSWA compared to the natural granite aggregate. Similar to this study, Nuruzzaman et al. [29] also reported an increase in density of concrete containing FNSWA. As they reported, the density increased by $1.58 \%, 3.15 \%$, and $4.73 \%$ due to the use of $20 \%$, $40 \%$, and $60 \%$ FNSWA. On the other hand, the opposite trend was reported by Bouasria et al. [49]. They, however, replaced not the aggregate but the cement with ferronickel slag, and noted a decrease in concrete density from 2390 to $2330 \mathrm{~kg} / \mathrm{m}^{3}$ after a $10 \%$ substitution. Further modifications also showed decreased values-2310 and $2300 \mathrm{~kg} / \mathrm{m}^{3}$ for $15 \%$ and 
$30 \%$ replacement of cement, respectively. This may be connected to a higher density of cement powder compared to ferronickel slag.

Table 6. Hardened concrete test results.

\begin{tabular}{cccccccc}
\hline Mix Symbol & $\begin{array}{c}\text { Density } \\
{\left[\mathbf{k g} / \mathbf{m}^{3} \text { ] }\right.}\end{array}$ & $\begin{array}{c}\text { Compressive } \\
\text { Strength } \\
{[\mathbf{M P a}]}\end{array}$ & $\begin{array}{c}\text { Split Tensile } \\
\text { Strength } \\
{[\mathbf{M P a}]}\end{array}$ & $\begin{array}{c}\text { Flexural } \\
\text { Strength } \\
{[\mathbf{M P a}]}\end{array}$ & $\begin{array}{c}\text { Modulus of } \\
\text { Elasticity } \\
{[\mathrm{GPa}]}\end{array}$ & $\begin{array}{c}\text { Poisson } \\
\text { Coefficient } \\
{[\mathrm{GPa}]}\end{array}$ & $\begin{array}{c}\text { Thermal } \\
\text { Conductivity } \\
{[\mathbf{W} / \mathbf{m K}]}\end{array}$ \\
\hline BM & $2187 \pm 2$ & $45 \pm 1$ & $2.87 \pm 0.03$ & $5.9 \pm 0.1$ & $31.5 \pm 0.4$ & $0.123 \pm 0.03$ & $1.88 \pm 0.04$ \\
\hline 5FNSW & $222 \pm 2$ & $49 \pm 1$ & $2.99 \pm 0.05$ & $6.2 \pm 0.1$ & $31.6 \pm 0.3$ & $0.124 \pm 0.03$ & $1.68 \pm 0.04$ \\
\hline 10FNSW & $2244 \pm 3$ & $53 \pm 1$ & $3.60 \pm 0.03$ & $6.5 \pm 0.1$ & $31.8 \pm 0.3$ & $0.129 \pm 0.04$ & $1.58 \pm 0.04$ \\
\hline 15FNSW & $2258 \pm 2$ & $54 \pm 1$ & $3.95 \pm 0.03$ & $7.4 \pm 0.1$ & $32.1 \pm 0.4$ & $0.123 \pm 0.03$ & $1.56 \pm 0.03$ \\
\hline 20FNSW & $2332 \pm 2$ & $56 \pm 1$ & $4.02 \pm 0.03$ & $9.5 \pm 0.2$ & $32.4 \pm 0.3$ & $0.124 \pm 0.04$ & $1.54 \pm 0.04$ \\
\hline 25FNSW & $2378 \pm 3$ & $59 \pm 1$ & $4.11 \pm 0.04$ & $9.8 \pm 0.1$ & $33.6 \pm 0.3$ & $0.123 \pm 0.03$ & $1.53 \pm 0.03$ \\
\hline
\end{tabular}

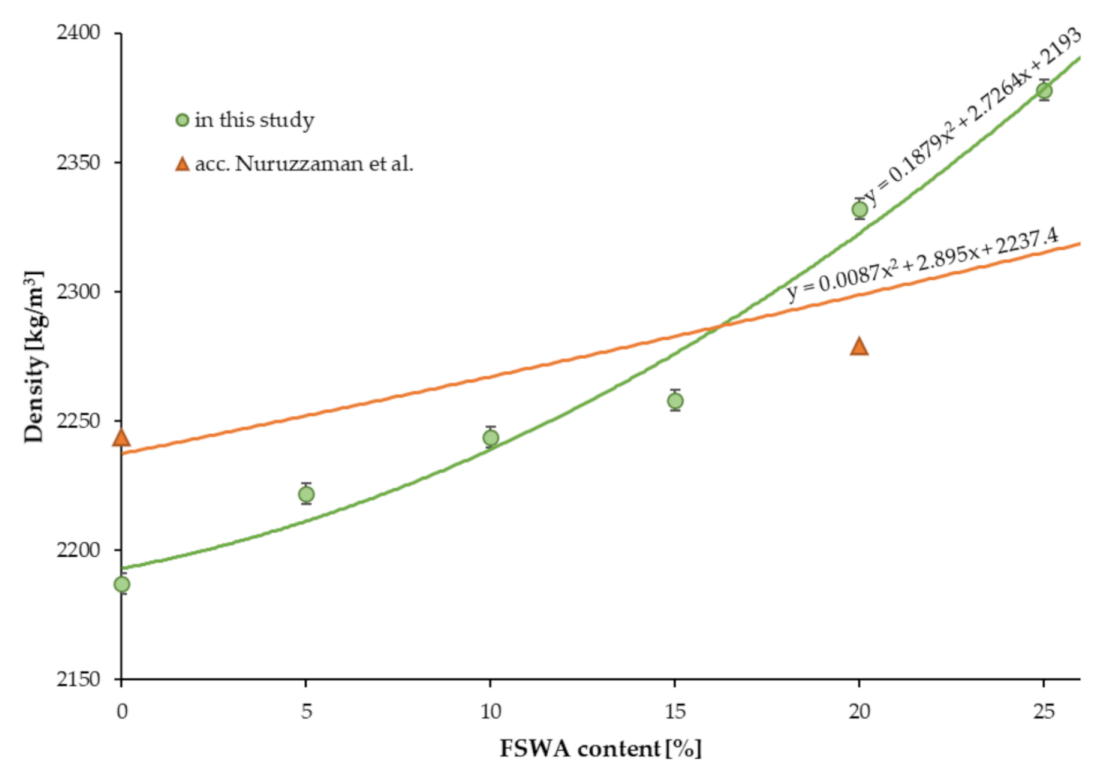

Figure 4. The impact of FNSWA on concrete density.

\subsection{Compressive Strength}

The results of compressive strength for samples with different contents of FNSWA are presented in Table 6 and in Figure 5. The results were compared to the base mix (without FNSWA), which showed a compressive strength of $45 \pm 1 \mathrm{MPa}$. All of the substitution of natural aggregate, equal to $5 \%, 10 \%, 15 \%, 20 \%$, and $25 \%$, indicated an increase in compressive strength by $8.8 \%, 17.8 \%, 20.0 \%, 24.4 \%$, and $31.1 \%$, respectively. For this case, the highest value of compressive strength $(59 \pm 1 \mathrm{MPa})$ was obtained for samples with the highest amount of FNSWA $\left(400 \mathrm{~kg} / \mathrm{m}^{3}\right)$. The same phenomena was reported by Qi et al. [31] as they noted the peak values of compressive strength for samples modified with $50 \%$ of FNSWA (44.6 MPa). Another study in line with this trend was published by Nuruzzaman et al. [29]. The authors tested the FNSW concrete with ferronickel slag grading up to $9.50 \mathrm{~mm}$ and density of $2920 \mathrm{~kg} / \mathrm{m}^{3}$ with its addition equal to $20 \%, 40 \%$, and $60 \%$. They reported similar values of compressive strength (52.15 MPa) for samples containing $20 \%$ of ferronickel slag compared to $20 \mathrm{FNSW}$ samples (56 $\pm 1 \mathrm{MPa}$ ). Moreover, Sun et al. [30] used two types of ferronickel slag for concrete manufacturing - blast furnace slag (BS) and electric furnace slag (ES). They showed that BS indicates an increase in compressive strength by about $6 \%, 9 \%$, and $11 \%$ for samples with $25 \%, 50 \%$, and $75 \%$ of ferronickel used as an aggregate. In the opposition to this were however results of ES concretes, as they presented a decrease in compressive strength with an increase in 
ferronickel slag content. The opposite trend noted for samples containing ES may be due to the type of ferronickel used, which showed a smooth surface. In turn, it can affect the interactions between components and lower the results of mechanical tests. The lowest compressive strength was reported for samples with $75 \%$ and $100 \%$ electric furnace slag (58 MPa) and compared to the reference sample ( $65 \mathrm{MPa})$, it was a decrease by about $11 \%$.

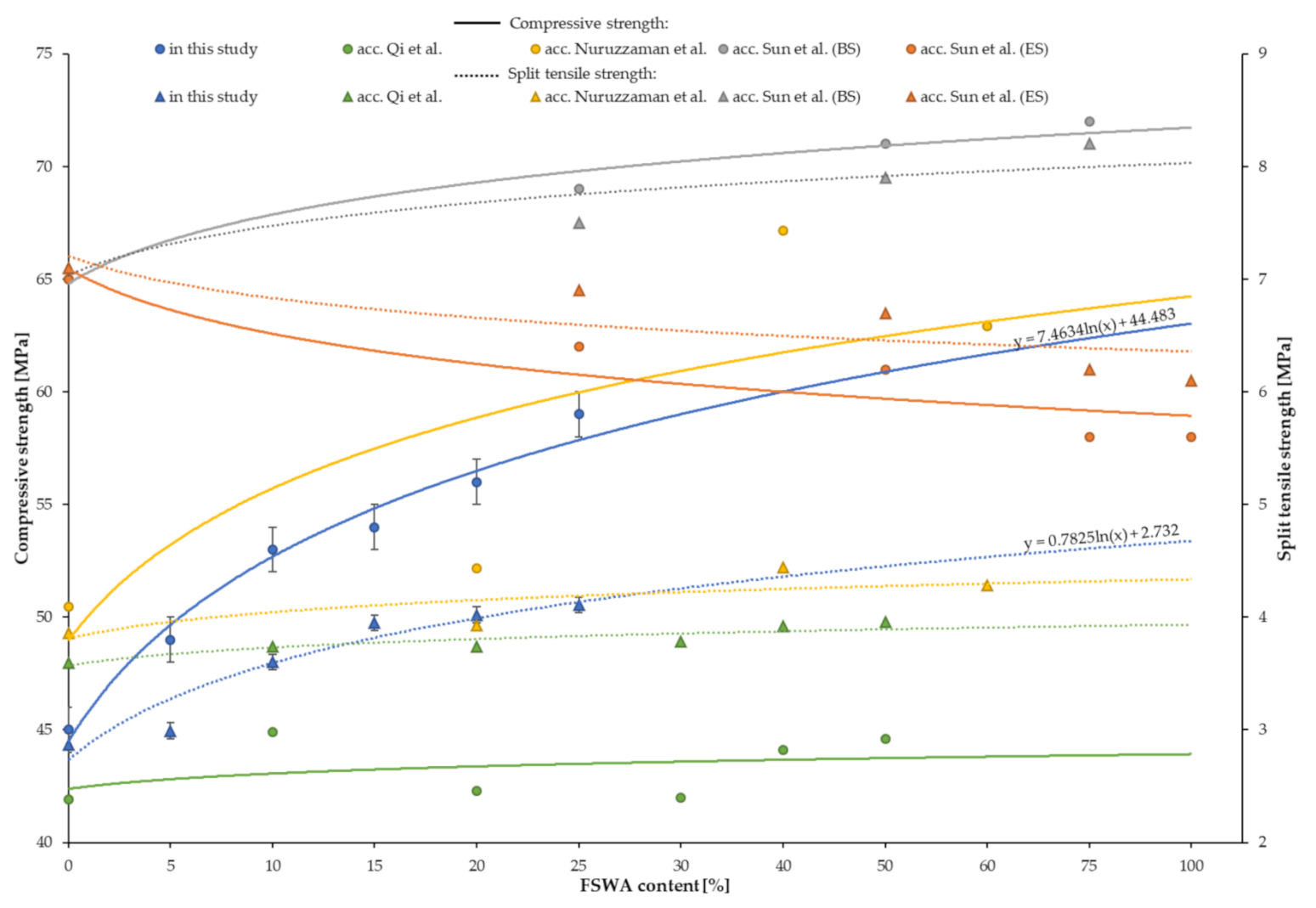

Figure 5. The impact of FNSWA on compressive strength and split tensile strength.

\subsection{Split Tensile Strength}

Table 6 shows the split tensile strength test results of concrete with a natural aggregate replacement done with FNSWA. After substitution of granite aggregate with 5\%, 10\%, 15\%, $20 \%$, and $25 \%$ of FNSWA, the linear increase in split tensile strength was reported, see Figure 6. Compared to BM, the samples modified with FNSWA showed higher values by around $4 \%, 25 \%, 38 \%, 40 \%$, and $43 \%$ values, respectively for 5FNSW, 10FNSW, $15 \mathrm{FNSW}$, 20FNSW, and 25FNSW samples. As observed, the difference in split tensile strength for the reference sample and the sample with the lowest amount of FNSWA $\left(80 \mathrm{~kg} / \mathrm{m}^{3}\right)$ was not significant. However, a further increase in FNSWA used in concrete resulted in a visible increase in the split tensile strength, what also was reported by Nuruzzaman et al. [29]. Their FNSW concrete showed a $2 \%, 15 \%$, and $11 \%$ increase in split tensile strength for $20 \%$, $40 \%$, and $60 \%$ ferronickel used as an aggregate. Furthermore, Qi et al. [31] tested FNSWA as a substitute to natural aggregate. They used five different contents of ferronickel equal to $10 \%, 20 \%, 30 \%, 40 \%$, and $50 \%$. As presented in their study, the highest split tensile strength $(3.96 \mathrm{MPa})$ showed samples with $50 \%$ of FNSWA, which was about $10 \%$ greater than plain concrete. An increasing trend was also reported for BS concretes tested by Sun et al. [30], however their ES concrete showed an opposite phenomena. This may be a result of ES particles that contain a number of smooth glass surfaces, which can seriously weaken the cohesion between cement paste and aggregates, and mechanical properties of hardened concrete. 


\subsection{Flexural Strength}

Table 6 presents the results of the flexural strength test of concrete samples with FNSWA. For the $5 \%, 10 \%, 15 \%, 20 \%$, and $25 \%$ substitution of natural granite aggregate, the obtained flexural strength was about average 5\%,10\%, 25\%, 61\%, and $66 \%$ higher than for the plain concrete $(5.9 \pm 0.1 \mathrm{MPa})$, respectively. The flexural strength is directly proportional to the FNSWA amount used in the concrete mixture, which is shown by a linear increase in values. Furthermore, the determined $R^{2}$ coefficient equal to 0.9 , means a good fit. This trend was also reported by Saha et al. [24], as well. They showed however, that a peak in flexural strength is achievable for 50\% FNSWA used in concrete and a further increase in the amount of natural aggregate substitute decreases this property. Their study complies with the Sun et al. research [30] as they reported after 28 days a constant value of flexural strength for samples modified with $50 \%$ and $75 \%$ of ferronickel slag ( $8.2 \mathrm{MPa}$ ). What is worth mentioning is that Sun et al. who used two types of the ferronickel slag described above reported an increase for BS concretes, when the electric furnace slag showed a decrease in flexural strength by about $4 \%, 6 \%, 10 \%$, and $12 \%$ for $25 \%, 50 \%, 75 \%$, and $100 \%$ natural aggregate replacement, respectively.

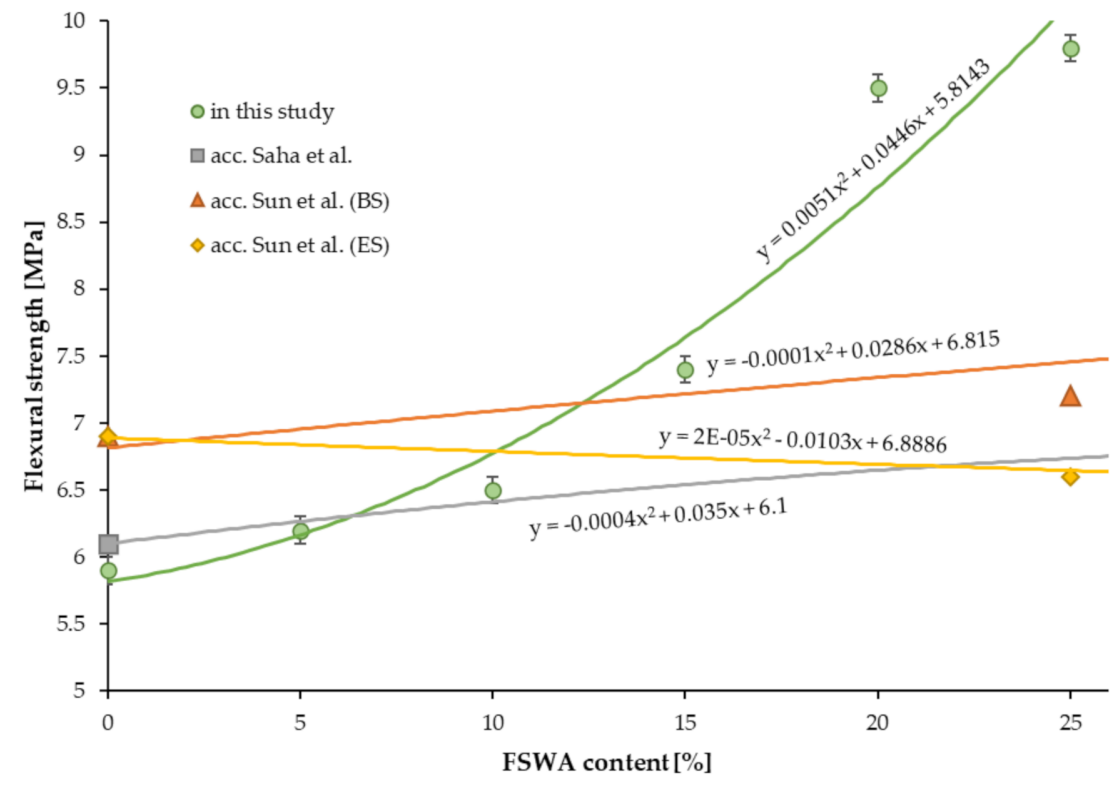

Figure 6. The impact of FNSWA on flexural strength.

\subsection{Modulus of Elasticity and Poisson's Coefficient}

The modulus of elasticity was slightly influenced by the aggregate substitution done with FNSWA. Results given in Table 6, range from $31.5 \pm 0.4$ to $33.6 \pm 0.3 \mathrm{GPa}$. The highest values of modulus of elasticity were reported for 25FNSW samples, which compared to BM showed a $6.7 \%$ increase in value. This trend was reported for the rest of the samples as well, as the noted values were higher than the plain concrete $(0.3 \%, 1.0 \%, 1.9 \%$, and $2.9 \%$ increase for 5FNSW, 10FNSW, 15FNSW, and 20FNSW samples, respectively). An increasing trend, after replacing $50 \%$ of natural sand aggregate with FNSWA, was reported by Sakoi et al. [50] and Saha and Sarker [26], as well. However, their increase was about $14 \%$ and $12 \%$, respectively, which is almost two times higher compared to this study. Such a difference was caused by the greater FNSWA amount used by other researchers, which could result in an increase of modulus of elasticity as it is related with the density of concrete components.

On the other hand, the results of the Poisson's ratio, presented in Table 6, indicate no influence of FNSWA to this concrete property, as they are in the measurement error range. Therefore, it can be said that the substitution of natural granite aggregate done with FNSWA in the range from $5 \%$ to $25 \%$ did not affect the Poisson's ratio. A similar conclusion was 
made by Qi et al. [31] as they stated that Poisson's ratio of concrete containing ferronickel slag is consistent with that of conventional concrete.

\subsection{Thermal Conductivity}

The obtained results of the thermal conductivity test ranged from 1.53 to $1.88 \mathrm{~W} / \mathrm{mK}$ (Table 6). The concrete modified with $25 \%$ FNSWA showed the lowest values of thermal conductivity, which were $18.6 \%$ less than the plain concrete. Moreover, a linear decreasing trend can be reported as thermal conductivity drops with an increase in the amount of the aggregate substitute. The same phenomena was reported by Saha et al. [32]. Their plain concrete reduced its thermal conductivity from 2.34 to $1.58 \mathrm{~W} / \mathrm{mK}, 1.65 \mathrm{~W} / \mathrm{mK}$, $1.36 \mathrm{~W} / \mathrm{mK}$, and $1.16 \mathrm{~W} / \mathrm{mK}$, with $25 \%, 50 \%, 75 \%$, and 100\% FNSWA replacement, respectively. As presented in Figure 7, the thermal conductivity values reported for concretes with $25 \%$ ferronickel slag waste in this study and by Saha et al. are almost equal.

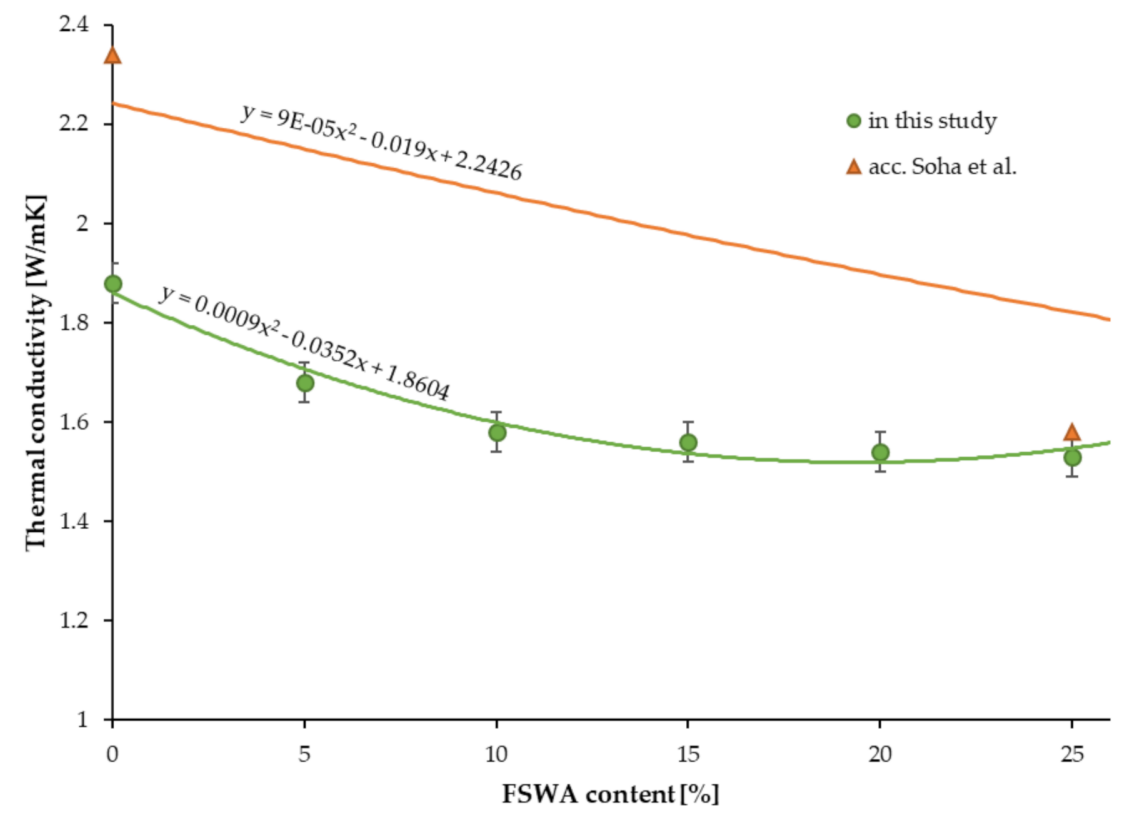

Figure 7. The impact of FNSWA on thermal conductivity.

\section{Conclusions}

The aim of this study was to evaluate the possibility of using the ferronickel slag waste aggregate stored in dumps in Szklary (Lower Silesian, Poland) as an aggregate substitute in concrete production. To do so, tests on new laboratory concrete mixtures were carried out, from which final key conclusions can be made:

- $\quad$ The highest air content was reported for 25FNSW samples (3.6\%);

- The density of hardened concretes were proportional to the amount of FNSWA used. The density increased with the increasing FNSWA and the highest density $\left(2378 \mathrm{~kg} / \mathrm{m}^{3}\right)$ was found for concrete with $25 \%$ FNSWA and the lowest density $\left(2187 \mathrm{~kg} / \mathrm{m}^{3}\right)$ for plain concrete;

- The substitution of $80,160,240,320$, and $400 \mathrm{~kg} / \mathrm{m}^{3}$ natural granite aggregate with FNSWA caused an increase in the compressive strength by about $1.09,1.18,1.20,1.24$, and 1.31 times and in flexural strength by about 1.05, 1.10, 1.25, 1.61, and 1.66 times, respectively compared to plain concrete, while the obtained split tensile strength was increased compared to BM by $4.0 \%, 25 \%, 38 \%, 40 \%$, and $43 \%$, respectively

- A slight influence of FNSWA on the modulus of elasticity was noted as reported values showed an increase in the range of $0.3 \%$ up to $6.7 \%$, depending on the amount of substitute used;

- All of the concretes with FNSWA showed lower thermal conductivity values compare to BM. The highest decrease was reported for $25 \mathrm{FNSW}$ samples $(18.6 \%)$; 
- The substitution of natural aggregate done with FNSWA did not affect consistency, the $\mathrm{pH}$ value, and Poisson's ratio of concrete.

This research presents a solution to air, soil, and groundwater pollution caused by the remains of post-war mining activities in Szklary (Lower Silesia, Poland). The set goal of this case study, which was to determine the physical, mechanical, and thermal properties of concretes containing FSWA, was successfully achieved. All of the new concretes showed increased strength parameters, crucial in building materials, which can indicate a great application capacity in the current construction industry.

Author Contributions: Conceptualization and methodology, M.M. and M.J.; investigation, M.M., M.J., W.Ł., K.D. and A.B.; data curation, M.J. and M.M.; formal analysis, M.J.; funding acquisition, M.M.; project administration, M.M.; resources, M.M., M.J. and W.Ł.; supervision, M.M.; validation, M.M. and M.J.; visualization, M.J.; writing—original draft preparation, M.J. and M.M.; writingreview and editing, M.M., M.J. and A.B. All authors have read and agreed to the published version of the manuscript.

Funding: This research received no external funding besides the statutory research of particular scientific units.

Institutional Review Board Statement: Not applicable.

Informed Consent Statement: Not applicable.

Data Availability Statement: Data is contained within the article.

Acknowledgments: This work was financially supported by the Dean of Faculty of Civil Engineering and Geodesy of the Military University of Technology as part of a scholarship no. 1/DHP/2020. The authors thank PROFIMA Sp. z o.o., ul. Wojciecha Żywnego 12/30, 02-701 Warsaw for providing the FSWA mined from ferronickel slag dump stored in Szklary (Lower Silesia, Poland) to conduct this research, and the fifth-year students, Bartosz Niewczas and Daniel Moch, for their help in preparing this article.

Conflicts of Interest: The authors declare no conflict of interest.

\section{References}

1. Technical Review, Supreme Technical Organization (Poland), Central Institute of Scientific, Technical and Economic Information (Poland), Warsaw, Poland; Central Office of Measures: Warsaw, Poland, 1984.

2. The Act of July 21, 1950 on the 6-Year Plan for Economic Development and Building the Foundations of Socialism for the Years. J. Laws 1950, 37, 344 .

3. Tighe, C. Forward to battle for the Six-Year Plan! Polish writers 1945-56. J. Eur. Stud. 2015, 45, 189-219. [CrossRef]

4. Pohoski, M. Interrelation between Social Mobility of Individuals and Groups in the Process of Economic Growth in Poland. Pol. Sociol. Bull. 1964, 10, 17-33.

5. Malina, G. Ecotoxicological and environmental problems associated with the former chemical plant in Tarnowskie Gory, Poland. Toxicology 2004, 205, 157-172. [CrossRef] [PubMed]

6. Berto, C.; Krajcarz, M.T.; Moskal-del Hoyo, M.; Komar, M.; Sinet-Mathiot, V.; Zarzecka-Szubińska, K.; Krajcarz, M.; Szymanek, M.; Wertz, K.; Marciszak, A.; et al. Environment changes during Middle to Upper Palaeolithic transition in southern Poland (Central Europe). A multiproxy approach for the MIS 3 sequence of Koziarnia Cave (Kraków-Częstochowa Upland). J. Archaeol. Sci. Rep. 2021, 35, 102723. [CrossRef]

7. dám Nádudvari, Á.; Fabiańska, M.J. Use of geochemical analysis and vitrinite reflectance to assess different self-heating processes in coal-waste dumps (Upper Silesia, Poland). Fuel 2016, 181, 102-119. [CrossRef]

8. Carras, J.N.; Day, S.J.; Saghafi, A.; Williams, D.J. Greenhouse gas emissions from low-temperature oxidation and spontaneous combustion at open-cut coal mines in Australia. Int. J. Coal. Geol. 2009, 78, 161-168. [CrossRef]

9. Central Statistical Office (GUS)-TERYT (National Register of Territorial Land Apportionment Journal). Available online: https://eteryt.stat.gov.pl/eTeryt/rejestr_teryt/udostepnianie_danych/baza_teryt/uzytkownicy_indywidualni/ wyszukiwanie/wyszukiwanie.aspx?contrast=default (accessed on 17 March 2021).

10. Institute of Mineral and Energy Economy of the Polish Academy of Sciences. Part I: Searching and recognition of defenses planning and organization of geological works. In Methodology for Documenting the Fold Solid Mines; Institute of Mineral and Energy Economy of the Polish Academy of Sciences: Cracow, Poland, 2012.

11. Polish Geological Institute-National Research Institute. Balance of Prospective Resources of Poland's Minerals at December 31, 2018; Polish Geological Institute-National Research Institute: Warsaw, Poland, 2020. 
12. Małek, M.; Łasica, W.; Jackowski, M.; Kadela, M. Effect of Waste Glass Addition as a Replacement for Fine Aggregate on Properties of Mortar. Materials 2020, 13, 3189. [CrossRef]

13. Szcześniak, A.; Zychowicz, J.; Stolarski, A. Influence of Fly Ash Additive on the Properties of Concrete with Slag Cement. Materials 2020, 13, 3265. [CrossRef]

14. Isa, M.; Pilakoutas, K.; Guadagnini, M.; Angelakopoulos, H. Mechanical performance of affordable and eco-efficient ultra-high performance concrete (UHPC) containing recycled tyre steel fibres. Constr. Build. Mater. 2020, 255, 119272. [CrossRef]

15. Jurczak, R.; Szmatuła, F.; Rudnicki, T.; Korentz, J. Effect of Ground Waste Glass Addition on the Strength and Durability of Low Strength Concrete Mixes. Materials 2021, 14, 190. [CrossRef]

16. Khankhaje, E.; Salim, M.R.; Mirza, J.; Hussin, M.W.; Rafieizonooz, M. Properties of sustainable lightweight pervious concrete containing oil palm kernel shell as coarse aggregate. Constr. Build. Mater. 2016, 126, 1054-1065. [CrossRef]

17. Bhat, J.A. Mechanical behaviour of self compacting concrete: Effect of wood ash and coal ash as partial cement replacement. Mater. Today Proc. 2021, 42, 1470-1476. [CrossRef]

18. Małek, M.; Jackowski, M.; Łasica, W.; Kadela, M. Characteristics of Recycled Polypropylene Fibers as an Addition to Concrete Fabrication Based on Portland Cement. Materials 2020, 13, 1827. [CrossRef]

19. Kim, S.B.; Yi, N.H.; Kim, H.Y.; Kim, J.H.J.; Song, Y.C. Material and structural performance evaluation of recycled PET fiber reinforced concrete. Cement. Concr. Comp. 2010, 32, 232-240. [CrossRef]

20. Małek, M.; Jackowski, M.; Łasica, W.; Kadela, M.; Wachowski, M. Mechanical and Materials Properties of Mortar Reinforced with Glass Fiber: An Experimental Study. Materials 2021, 14, 698. [CrossRef]

21. Małek, M.; Łasica, W.; Kadela, M.; Kluczyński, J.; Dudek, D. Physical and Mechanical Properties of Polypropylene Fibre-Reinforced Cement-Glass Composite. Materials 2021, 14, 637. [CrossRef]

22. Jackowski, M.; Małek, M.; Życiński, W.; Łasica, W.; Owczarek, M. Characterization of new recycled polymers shots addition for the mechanical strength of concrete. Mater. Technol. 2020, 54, 355-358. [CrossRef]

23. Kōmura, S.; Takeda, T.; Ōhara, S. Magnetic Diffuse Scattering of Neutrons from Fe-Ni Invar Alloy. J. Phys. Soc. Jpn. 1973, 35, 706-711. [CrossRef]

24. Saha, A.K.; Sarker, P.K. Sustainable use of ferronickel slag fine aggregate and fly ash in structural concrete: Mechanical properties and leaching study. J. Clean. Prod. 2017, 162, 438-448. [CrossRef]

25. Saha, A.K.; Khan, M.N.N.; Sarker, P.K. Value added utilization of by-product electric furnace ferronickel slag as construction materials: A review. Resour. Conserv. Recycl. 2018, 134, 10-24. [CrossRef]

26. Saha, A.K.; Sarker, P.K. Compressive strength of mortar containing ferronickel slag as replacement of natural sand. Proc. Eng. 2017, 171, 689-694. [CrossRef]

27. Saha, A.K.; Sarker, P.K. Durability of mortar incorporating ferronickel slag aggregate and supplementary cementitious materials subjected to wet-dry cycles. Inter. J. Concr. Struct. Mater. 2018, 12, 29. [CrossRef]

28. Nguyen, Q.D.; Castel, A.; Kim, T.; Khan, M.S.H. Performance of fly ash concrete with ferronickel slag fine aggregate against alkali-silica reaction and chloride diffusion. Cem. Concr. Res. 2021, 139, 106265. [CrossRef]

29. Nuruzzaman, M.; Casimiro, J.O.C.; Sarker, P.K. Fresh and hardened properties of high strength self-compacting concrete using by-product ferronickel slag fine aggregate. J. Build. Eng. 2020, 32, 101686. [CrossRef]

30. Sun, J.; Feng, J.; Chen, Z. Effect of ferronickel slag as fine aggregate on properties of concrete. Constr. Build. Mater. 2019, 206, 201-209. [CrossRef]

31. Qi, A.; Liu, X.; Wang, Z.; Chen, Z. Mechanical properties of the concrete containing ferronickel slag and blast furnace slag powder. Constr. Build. Mater. 2020, 231, 117120. [CrossRef]

32. Saha, A.K.; Sarker, P.K.; Golovanevskiy, V. Thermal properties and residual strength after high temperature exposure of cement mortar using ferronickel slag aggregate. Constr. Build. Mater. 2019, 199, 601-612. [CrossRef]

33. European Committee for Standardization. EN 197-1:2012 Cement-Part 1: Composition, Specifications and Conformity Criteria for Common Cements; European Committee for Standardization: Brussels, Belgium, 2012.

34. European Committee for Standardization. EN 196-6:2019-01 Methods of Testing Cement_Part 6: Determination of Fineness; European Committee for Standardization: Brussels, Belgium, 2019.

35. European Committee for Standardization. EN 196-1:2016-07 Methods of Testing Cement_Part 1: Determination of Strength; European Committee for Standardization: Brussels, Belgium, 2016.

36. Rudnicki, T. The method of aggregate skeleton in self compacting concrete designing with segment regression. Cem. Wapno Beton. 2016, 1, 10-19. [CrossRef]

37. European Committee for Standardization. EN 12620+A1:2010 Aggregates for Concrete; European Committee for Standardization: Brussels, Belgium, 2010.

38. Górażdże Group: Cement, Concrete, Aggregate. Technical Data Sheet CEM I 42.5 R. Available online: http://www.gorazdze.pl (accessed on 14 December 2020).

39. Rudnicki, T. Functional Method of Designing Self-Compacting Concrete. Materials 2021, 14, 267. [CrossRef]

40. European Committee for Standardization. EN 12390-2:2019-07 Testing Hardened Concrete_Part 2: Making and Curing Specimens for Strength Tests; European Committee for Standardization: Brussels, Belgium, 2019.

41. European Committee for Standardization. EN 12350-2:2019-07 Testing Fresh Concrete_Part 2: Slump Test; European Committee for Standardization: Brussels, Belgium, 2019. 
42. European Committee for Standardization. EN 12350-7:2019-08 Testing Fresh Concrete—Part 7: Air Content—Pressure Method; European Committee for Standardization: Brussels, Belgium, 2019.

43. Polish Committee for Standardization. PN-B-01810:1986 Protection Against Corrosion in Building-Protective Properties of Concrete Referring to Reinforcing Steel_Electrochemical Tests; Polish Committee for Standardization: Brussels, Belgium, 1986.

44. European Committee for Standardization. EN 12390-7:2019-08 Testing Hardened Concrete—Part 7: Density of Hardened Concrete; European Committee for Standardization: Brussels, Belgium, 2008.

45. European Committee for Standardization. N 12390-3:2019-07 Testing Hardened Concrete_Part 3: Compressive Strength of Test Specimens; European Committee for Standardization: Brussels, Belgium, 2019.

46. European Committee for Standardization. EN 12390-5:2019-08 Testing Hardened Concrete—Part 5: Flexural Strength of Test Specimens; European Committee for Stand-ardization: Brussels, Belgium, 2019.

47. European Committee for Standardization. EN 12390-6:2011 Testing Hardened Concrete_Part 6: Tensile Splitting Strength of Test Specimens; European Committee for Standardization: Brussels, Belgium, 2011.

48. European Committee for Standardization. EN 12390-13:2014-02 Testing Hardened Concrete—Part 13: Determination of Secant Modulus of Elasticity in Compression; European Committee for Standardization: Brussels, Belgium, 2014.

49. Bouasria, M.; Khadraoui, F.; Benzaama, M.-H.; Touati, K.; Chateigner, D.; Gascoin, S.; Pralong, V.; Orberger, B.; Babouri, L.; El Mendili, Y. Partial substitution of cement by the association of Ferronickel slags and Crepidula fornicata shells. J. Build. Eng. 2021, 33, 101587. [CrossRef]

50. Sakoi, Y.; Aba, M.; Tsukinaga, Y.; Nagataki, S. Properties of concrete used in ferronickel slag aggregate. In Proceedings of the 3rd International Conference on Sustainable Construction Materials and Technologies, Tokyo, Japan, 19-21 August 2013; pp. 1-6. 